\title{
Oral Milataxel
}

National Cancer Institute

\section{Source}

National Cancer Institute. Oral Milataxel. NCI Thesaurus. Code C77880.

An orally bioavailable taxane with potential antineoplastic activity. Upon oral

administration, milataxel and its major active metabolite $\mathrm{M}-10$ bind to and stabilize

tubulin, resulting in the inhibition of microtubule depolymerization and cell division, cell

cycle arrest in the G2/M phase, and the inhibition of tumor cell proliferation. Unlike other taxane compounds, milataxel appears to be a poor substrate for the multidrug

resistance (MDR) membrane-associated P-glycoprotein (P-gp) efflux pump and may be useful for treating multidrug-resistant tumors. 